Sains Malaysiana 49(7)(2020): 1719-1727

http://dx.doi.org/10.17576/jsm-2020-4907-22

\title{
Nigella sativa as a Galactagogue: A Systematic Review
}

(Nigella sativa sebagai Penggalak Susu: Suatu Ulasan Sistematik)

\author{
Aini FARZANA ZULKEFLi, RusZYMAH BT Hu IDRUS \& AdILA A HAMID*
}

\begin{abstract}
Nigella sativa is a herb with various pharmacological properties and has been used widely for medicinal purposes and acts as a milk booster. The aim of this systematic review was to provide information on the galactagogue property of N. sativa. Electronic searches were conducted in two databases, namely, Medline via EBSCOhost and Scopus, for relevant studies published between the 1865 and March 2020. Additional records identified through Google Scholar showed one eligible article. Only articles published in English and related to the galactagogue effect of N. sativa were included in this review. A total of 110 potential articles were identified, but only four fulfilled the inclusion criteria. Four animal studies were included in this review. All of the selected studies reported positive galactagogue effects of $\mathrm{N}$. sativa as determined by serum prolactin level, breast tissue changes, milk production and composition, and weight of litter, thereby suggesting its effect as milk booster. However, the review found no evidence supporting the effect of $\mathrm{N}$. sativa as a galactagogue in humans.
\end{abstract}

Keywords: Breastfeeding; galactagogue; milk production; Nigella sativa

\section{ABSTRAK}

Nigella sativa merupakan sejenis herba yang mempunyai pelbagai ciri farmakologi dan telah digunakan secara meluas bagi tujuan perubatan dan juga sebagai penggalak susu. Ulasan sistematik ini menyediakan maklumat mengenai aktiviti N. sativa sebagai penggalak susu dengan mengenal pasti penerbitan yang berkaitan dengannya. Pencarian artikel secara elektronik dilakukan dengan menggunakan dua pangkalan data iaitu Medline melalui EBSCOhost dan Scopus dan artikel yang relevan antara tahun 1865 dan Mac 2020 dikenal pasti. Rekod tambahan telah dikenal pasti melalui Google Scholar iaitu sebanyak satu artikel. Sejumlah 110 artikel yang berpotensi dikenal pasti dan hanya empat artikel menepati kriteria yang ditetapkan. Empat kajian haiwan dimasukkan di dalam ulasan ini. Kesemua kajian menunjukkan kesan positif penggalak susu oleh N. sativa melalui penentuan aras prolaktin dalam serum, perubahan tisu payudara, penghasilan dan komposisi susu dan berat anak haiwan yang disusui. Hasil kajian seterusnya mencadangkan N. sativa sebagai agen penggalak susu. Namun begitu, ulasan sistematik ini mendapati tiada bukti yang menyokong kesan N. sativa sebagai penggalak susu pada manusia.

Kata kunci: Nigella sativa; penghasilan susu; penggalak susu; penyusuan

\section{INTRODUCTION}

Breastfeeding provides several benefits for both mothers and babies. All essential ingredients for the baby's development are provided in breastmilk. Breastmilk also prevents the development of several chronic diseases. Breastfeeding plays a role in the baby's immune system development, nutrient absorption, and neurodevelopment and in maternal psychological well-being (Othman et al. 2014).

In addition, women who breastfeed have reduced risk of developing breast and ovarian cancers. With each year that women breastfeed, the risk of developing breast cancer is reduced by $7 \%$ (Anstey et al. 2017). Furthermore, a prolonged period of breastfeeding is associated with reduced incidence of ovarian cancer (Jordan et al. 2012). The World Health Organization (WHO) recommends breastmilk as the only source of nutrition for infants until the age of 6 months. In Islam, a mother is encouraged to breastfeed her baby up to 2 years old.

According to the National Health Morbidity Survey 2016 (IPH 2016), the rate of babies that were exclusively breastfed up to 6 months in Malaysia did not achieve the WHO global nutrition targets of 2025 (WHO 2017) even after the National Breastfeeding and Infant Feeding Policy by the Ministry of Health Malaysia has been implemented. In addition, various campaigns on the benefits of breastfeeding have also 
been conducted by non-government organizations to create breastfeeding awareness among mothers. Despite the increasing trend of breastfeeding in Malaysia, the duration of breastfeeding remains low due to challenges faced by mothers in breastfeeding their babies. Among breastfeeding mothers, $54.4 \%$ discontinued breastfeeding exclusively as early as 1 month postpartum due to the delayed initiation of breastfeeding and difficulties in breastfeeding (Tengku Alina et al. 2013). The key challenges that most mothers encounter is the perception of insufficient milk supply that may lead to the cessation of milk production. The mother's medical problem and poor breastfeeding technique also hinder breastfeeding. To overcome the insufficient milk supply, women have used galactagogues.

Galactagogues are defined as substances or medicine that help to initiate and maintain adequate milk supply (Zuppa et al. 2010). They include conventional medicine or substances of herbal origin. Conventional medicines that are commonly used clinically are domperidone and metoclopramide. Both medicines increase serum prolactin level, thereby increasing milk supply and production. These medicines act by blocking the dopamine receptor in the central nervous system, resulting in an increase of prolactin synthesis by lactotroph cells in the anterior pituitary. However, both medicines have been reported to have adverse effects on mothers. Metoclopromide can cross the blood-brain barrier, resulting in central nervous system side effects, such as involuntary movement, dizziness, and headache (Hale et al. 2018). Furthermore, a high dose of domperidone is associated with gastrointestinal disorders, headache, and increased risk of cardiac problems (Anderson 2013; Doggrell \& Hancox 2014).

Alternatively, women throughout the world choose to use herbal sources as galactagogues, because herbal galactagogues are believed to be safe and easily available in the market. Herbal supplements that have been associated with galactagogue effect are shatavari (Asparagus racemosus) (Sharma \& Bhatnagar 2011), fennel (Foeniculum vulgare) (Hale \& Hartmann 2007), fenugreek (Trigonella foenum-gracum) (Liu et al. 2015), and black seed (Nigella sativa) (Hosseinzadeh et al. 2013).

N. sativa commonly grows in Eastern Europe, Middle East, and Western Asia and belongs to Ranunculaceae family. The tiny seeds of $N$. sativa are dark black in color, hence its common name 'Habba Al-Barakah' or 'Habba Al-Sauda' in Arabic and black seed in English. Both the seed and oil of $N$. sativa are very popularly used in ancient remedies to treat various ailments and diseases (Unani, Ayurveda, Chinese, and Arabic) in Asian countries and the Middle East (Aljabre et al. 2015). In Islamic literature, $N$. sativa is a great healing medicine, as it was mentioned in a Prophetic hadith. Moreover, the uses of $N$. sativa seeds have also been documented by Ibne-Sina (980-1037), a renowned Muslim scholar in his famous book, Al-Qanoon fi el-Tibb (Aljabre et al. 2015).

The chemical composition and therapeutic potential of $N$. sativa have been extensively studied using in vitro and in vivo models (Aljabre et al. 2015; Babazadeh et al. 2012; Nasuti et al. 2019). The major active compounds isolated and identified in $N$. sativa seeds are thymoquinone (30-48\%), p-cymene (7-15\%), carvacrol (6-12\%), 4-terpineol (2-7\%), t-anethole (1-4\%), and sesquiterpene longifolene (1-8\%) (Ali \& Blunden 2003; Boskabady \& Shirmohammadi 2002; Huchchannanavar et al. 2019). The seeds reportedly contain fats (28.5\%), proteins $(26.7 \%)$, carbohydrates $(24.9 \%)$, and total ash (4.8\%). They also contain vitamins and minerals, such as $\mathrm{Cu}, \mathrm{Fe}, \mathrm{P}$, and $\mathrm{Zn}$ (AI-Jassir 1992; Nickavar et al. 2003). Interestingly, the composition of $N$. sativa varies depending on its origin (Haron et al. 2014). N. sativa has various pharmacological properties, including antioxidant (Erboga et al. 2016), anti-schistosomiasis (El Shenawy et al. 2008), anti-fungal (Kul'ko et al. 2016), anti-diabetic (El Rabey et al. 2017), anti-cancer ( $\mathrm{Ng}$ et al. 2011) anti-inflammatory (Alemi et al. 2013), anti-hypertensive (Jaarin et al. 2015), anti-malaria (Abdulelah et al. 2007), anti-osteoporotic (Shuid et al. 2012), and hepatoprotective properties (Yesmin et al. 2013). Furthermore, N. sativa possesses galactagogue effects and helps stimulate milk production in rats (Hosseinzadeh et al. 2013). However, the galactagogue effects of $N$. sativa in humans is yet to be determined. Regarding acute and chronic toxicity, $N$. sativa fixed oil has low toxicity, as indicated by high $\mathrm{LD}_{50}$ values and biochemical and histopathological changes in rodents (Zaoui et al. 2002).

Despite several narrative reviews on the pharmacological effects of $N$. sativa, reviews on its galactagogue effect are limited. Therefore, the purpose of this study was to systematically review existing studies on the galactagogue effect of $N$. sativa and to provide information on the topic for further research.

\section{MATERIALS AND METHODS}

A computerized literature search was conducted to identify the original research articles reporting the potential of $N$. sativa as a natural herb galactagogue. The literature search was conducted using two databases, Medline via EBSCOhost (articles published between 1865 and March 2020) and Scopus (articles published between 1823 and March 2020) with the following keywords: 'Nigella sativa or black cumin' and 'galactagogue or lactation or prolactin'. In order to find literatures that might be missed during the database search, additional record was identified through Google Scholar using similar set of keywords. 


\section{STUDY INCLUSION AND EXCLUSION CRITERIA}

The eligible articles were reviewed independently by two authors (AFZ and AAH) based on the following criteria: Only full-text articles published in English were included; reported the galactogogue effect of $N$. sativa such as changes in milk production and composition, breast tissue and hormones involved in breastfeeding. Review articles, news, case reports, book chapters, conference proceedings, and editorial letters were excluded.

\section{DATA EXTRACTION AND MANAGEMENT}

Selection of the articles was conducted in two stages. In the first stage, the titles and abstracts of the articles were screened. The studies that did not fulfill the inclusion criteria were excluded. In the second stage, the full-text of selected articles was retrieved and reviewed based on the same inclusion and exclusion criteria. The sample size, type of animal involved, study design, results and conclusion were recorded in Table 1.

\section{RESULTS AND DISCUSSION}

The literature search from two electronic databases identified 110 potentially relevant articles, of which 88 articles were from Medline via EBSCOhost, 21 articles from Scopus and one article from Google Scholar. A total of 105 articles were excluded after reviewing the titles and abstracts. Full-text papers were obtained for

TABLE 1. Summary of selected studies included in the review

\begin{tabular}{|c|c|c|c|c|}
\hline Reference & Type of animal & Study design & Result & Conclusion \\
\hline $\begin{array}{l}\text { Abo El-Nor et } \\
\text { al. (2007) }\end{array}$ & $\begin{array}{l}\text { Buffalo } \\
(N=15, n=3)\end{array}$ & $\begin{array}{l}\text { Lactating buffaloes were randomly divided } \\
\text { into } 5 \text { experimental treatments; } \\
\text { (1) Control, concentrated feed mixture } \\
\text { (CFM) and rise straw (RS) }(2) \mathrm{T}_{1} \text {, control } \\
+200 \mathrm{~g} \text { of fenugreek seeds } \mathrm{h}-1 \text { day }^{-1}(3) \mathrm{T}_{2} \text {, } \\
\text { control }+50 \mathrm{~g} \text { of caraway seeds } \mathrm{h}^{-1} \text { day }^{-1} \\
(4) \mathrm{T}_{3} \text {, control }+50 \mathrm{~g} \text { of } N \text {. sativa seeds h-1 } \\
\text { day }^{-1} \text {; and (5) } \mathrm{T}_{4} \text {, control+100g Lepidium } \\
\left.\text { sativum seeds } \mathrm{h}^{-1} \text { day }{ }^{-1}\right) \\
\text { Duration of experiment: } 4 \text { weeks before } \\
\text { calving and extended for } 12 \text { weeks after } \\
\text { parturition. } \\
\text { Experimental parameters: Lactating } \\
\text { buffaloes were machine milked twice daily, } \\
\text { and milk yield was recorded daily for } 12 \\
\text { weeks. Milk samples were analyzed for } \\
\text { fat, total solids (TS), total protein (TP) ash, } \\
\text { lactose, and solid non-fat (SNF) } \\
\text { The blood plasma of lactating buffaloes was } \\
\text { collected for the evaluation of plasma total } \\
\text { protein, albumin, urea, glucose, plasma } \\
\text { glutamic-oxaloacetate-transaminase } \\
\text { (GOT), glutamic-pyruvate-transaminase } \\
\text { (GPT), globulin and albumin/globulin } \\
\text { ratio, creatinine, total lipids, cholesterol, } \\
\text { and alkaline phosphatase }\end{array}$ & $\begin{array}{l}\uparrow \text { Significantly higher } \\
\text { milk yield from week } \\
1-6 \text { in all treated groups } \\
\text { compared with control } \\
\downarrow \text { Significantly lower } \\
\text { milk yield from week } \\
7-12 \text { until the } 12 \text { th week } \\
\text { in all groups } \\
\uparrow \text { Significantly higher } \\
\text { increase in milk solid } \\
\text { non-fat content in } \mathrm{T}_{4}, \mathrm{~T}_{1}, \\
\text { and } \mathrm{T}_{2} \text { than in } \mathrm{T}_{3} \text { and the } \\
\text { control } \\
\uparrow \text { Significantly higher } \\
\text { increase in milk lactose } \\
\text { content in } \mathrm{T}_{1}, \mathrm{~T}_{4}, \mathrm{~T}_{3} \text { than } \\
\text { in } \mathrm{T}_{2} \text { and the control } \\
\text { Milk fat, total solids, } \\
\text { total prote in, and } \\
\text { ash content were not } \\
\text { significantly different } \\
\text { between treatments } \\
\uparrow \text { Significantly higher } \\
\text { increase in the daily TS, } \\
\text { SNF, TP, and lactose } \\
\text { yields in } \mathrm{T}_{1} \text { and } \mathrm{T}_{4} \text { than } \\
\text { in } \mathrm{T}_{2} \text { and } \mathrm{T}_{3} \text { compared } \\
\text { with control } \\
\uparrow \text { Significantly higher }_{\text {milk fat yield in } \mathrm{T}_{1} \text { than }} \\
\text { in } \mathrm{T}_{3}, \mathrm{~T}_{4}, \mathrm{~T}_{2} \text { and the } \\
\text { control }\end{array}$ & $\begin{array}{l}\text { Supplementation of } \\
\text { lactating buffalo's diet } \\
\text { with medicinal plants, } \\
\text { such as fenugreek, } N \text {. } \\
\text { sativa, and Lepidium } \\
\text { sativum may improve the } \\
\text { productive performance } \\
\text { of lactating buffaloes } \\
\text { in terms of milk yield, } \\
\text { composition, and feed } \\
\text { efficiency }\end{array}$ \\
\hline
\end{tabular}


No significant

differences among the

different treatments

in globulin, albumin/

globulin ratio,

urea, GOT, alkaline

phosphatase, total

lipids, and cholesterol

Total protein, albumin, creatinine, GPT, and

glucose increased

significantly $(\mathrm{p}<0.05)$ in

different groups

\begin{tabular}{ll}
\hline Nurdin et al. & $\begin{array}{l}\text { Holland Cow } \\
(2011)\end{array}$ \\
$(N=20, n=4)$
\end{tabular}

Fries Holland lactating cows (bodyweight

of $350 \mathrm{~kg}$ and milk production of $10-$

milk Herb supplementation

12 liters/head/day) with suspected

yield (2.83-4.86\%) (black cumin, Curcuma

bacterial pathogens (Staphylococcus, than the control group aeruginosa) may be

Streptococcus, Escherichia coli, and

Corynebacterium) were divided into five groups of treatments: (1) non-herb, (2) significantly decreased milk yield and enhance $0.03 \%$ body weight of black cumin, (3) milk fat $(\mathrm{P}>0.05)$

milk quality

$0.02 \%$ body weight of Curcuma zedoaria,

(4) $0.06 \%$ body weight of Curcuma mangga, and (5) $0.02 \%$ body weight of

Curcuma aeruginosa

Duration of experiment: 3 months

Experimental parameters: Milk yield at $4 \%$ fat corrected milk (L), milk fat (\%), milk protein (\%), milk lactose (\%), and mastitis status as measured by IPB-1 reagent (indirect method of mastitis)

$\begin{array}{ll}\text { Hosseinzadeh } & \text { Rodent } \\ \text { et al. (2013) } & (\mathrm{N}=30, \mathrm{n}=6)\end{array}$

For milk production, 30 lactating dams were divided into five groups and received saline and aqueous and ethanolic extracts of $N$. sativa at 0.5 and $1 \mathrm{~g} / \mathrm{kg}$

Duration of study: $23 \mathrm{~h}$

Experimental parameters: Milk production and weight of pups were measured. For acute toxicity test, different doses of aqueous and ethanolic extracts of $N$. sativa were administrated orally and intraperitoneally to groups of six male and female albino mice. The number of deaths at $48 \mathrm{~h}$ after treatment was recorded $\uparrow$ Significantly of milk Aqueous and ethanolic production and pup extracts of $N$. sativa weight $23 \mathrm{~h}$ after gavage stimulates $\mathrm{milk}$ in aqueous $(0.5 \mathrm{~g} / \mathrm{kg})$ and production in rats ethanolic extracts $(1 \mathrm{~g} /$ $\mathrm{kg}$ ) groups

No mortality was observed in mice administered with aqueous and ethanolic extracts of $N$. sativa with LD50 of $4.23 \mathrm{~g} / \mathrm{kg}$ (aqueous extract) and 4.9 $\mathrm{g} / \mathrm{kg}$ (ethanolic extracts)

\begin{tabular}{ll}
\hline Al-Snafi et & Mice \\
al. $(2014)$ & $(\mathrm{N}=48, \mathrm{n}=24)$
\end{tabular}

Forty-eight lactating albino mice with 3 litters for each female were divided into 2 groups, namely, (1) control diet (2) $N$. sativa diet

Duration of study: 15 days

Experimental parameters: Weight of the litter at first and 15th days of age, serum prolactin level, and breast tissue histology of lactating mice $\uparrow$ Significantly increased litter weight of lactating mice on $N$. sativacontaining diet compared with the control

$\uparrow$ Significantly increased serum prolactin level in lactating mice on $N$. sativa-containing diet compared with the control
N.sativa exhibits prolactin stimulatory activity and may stimulate the production of milk in mice 
The breast tissue of lactating mice on $N$. sativa-containing diet showed large acini with more secretory activity and increased proliferation and thickness of the epithelium compared with the control group

remaining five papers. Finally, one paper was excluded by reading the full-text thoroughly as the paper reported the effect of $N$. sativa treatment on cows with subclinical mastitis, however no result on the effect of $N$. sativa on its galactagogue effect was reported (Azadi et al. 2010). A flowchart of the selection process is shown in Figure 1.

\section{STUDY DESIGN CHARACTERISTICS}

A summary of the characteristics of all studies is displayed in Table 1. All studies were published between 2007 and 2014. All studies were conducted using animals, namely, rats (Hosseinzadeh et al. 2013), albino mice (AlSnafi et al. 2014), buffaloes (Abo El-Nor et al. 2007), and cows (Nurdin et al. 2011). Three studies originated from
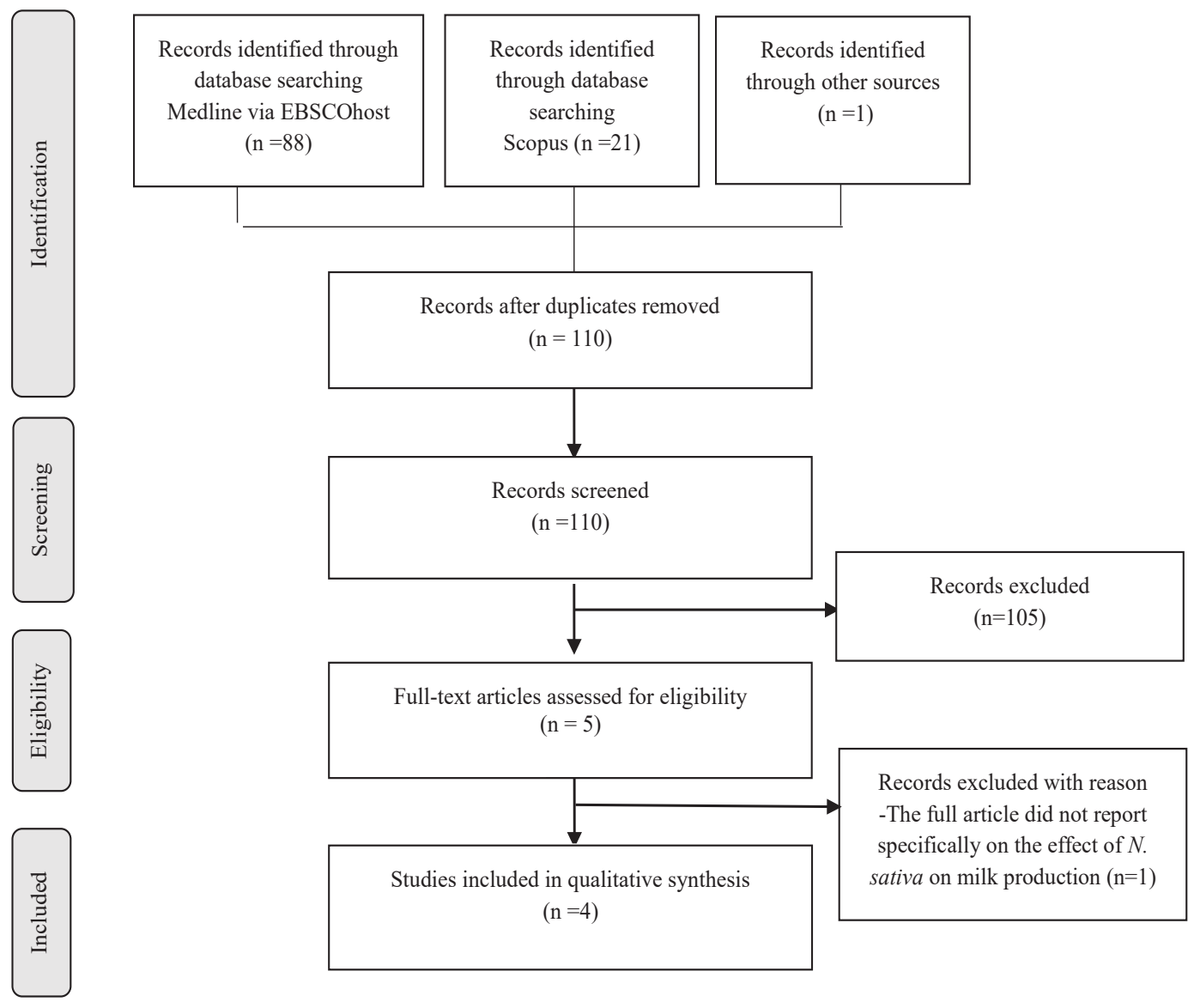

FIGURE 1. Flow chart of the literature search 
the Middle East countries, namely, Iran, Iraq, and Egypt. One study originated from Indonesia. In addition to $N$. sativa, other herbs, such as fenugreek seeds, caraway seeds, lepidium seeds (Abo El-Nor et al. 2007), Curcuma zedoaria, C. mangga, and C. aeruginosa (Nurdin et al. 2011), were included in two studies.

In all included studies, the galactagogue effect of $N$. sativa was determined on the basis of these four parameters, as follows: serum prolactin level; milk composition and yield; litter's body weight; and changes of breast tissue as determined through histology. Other than these parameters, one study evaluated hematological and biochemical values of the animals fed with $N$. sativa (Abo El-Nor et al. 2007), and another study determined its toxicity (Hosseinzadeh et al. 2013). Three studies used $N$. sativa seeds in powder form (Abo ElNor et al. 2007; Al-Snafi et al. 2014; Nurdin et al. 2011), whereas one used the aqueous and ethanolic extracts of the seeds (Hosseinzadeh et al. 2013). N. sativa extract was administered to the animals by oral gavage (AlSnafi et al. 2014; Hosseinzadeh et al. 2013) and as food supplement (Abo El-Nor et al. 2007; Nurdin et al. 2011).

Out of four selected studies, only one (Nurdin et al. 2011) used lactating cows suspected with mastitis. The three other studies used healthy lactating animals (Abo El-Nor et al. 2007; Al-Snafi et al. 2014; Hosseinzadeh et al. 2013). Despite the different methods adopted in each study, the results indicated positive galactagogue effect in animals treated with $N$. sativa compared with the control.

The galactagogue action of $N$. sativa was clearly illustrated in all included studies by measuring serum prolactin level, breast tissue changes, milk production and composition, and the weight of litter. Prolactin is a hormone that is involved directly in breastfeeding. During pregnancy, the level of prolactin in blood increases. However, milk secretion is inhibited by the high serum progesterone and estrogen levels. Immediately following childbirth and placental expulsion, progesterone, and estrogen levels fall dramatically, and milk secretion begins due to the action of prolactin and is stimulated by suckling of the litter. Out of the four studies included in this review, only one tested the galactagogue action of $N$. sativa by measuring the serum prolactin level of female lactating mice fed on diet supplemented with $N$. sativa (Al-Snafi et al. 2014). The serum prolactin level of the lactating female mice fed with the diet was significantly higher compared with the control group.

The initiation phase of lactogenesis also involved changes in breast tissue, which include an increase in size and number of lobules and enlargement of epithelial cells. Among the included studies, one study examined the histology of breast tissue of lactating mice (Al-Snafi et al. 2014). A section of breast tissue in female mice fed with $N$. sativa-containing diet had larger acini, thicker epithelial cells, and more secretory activity compared with the control group. The hyperactivity of breast tissue of the female mice fed on $N$. sativa well correlated with the increase in serum prolactin. This result may be due to the role of prolactin in stimulating breast tissue growth and development during pregnancy and lactation.

Milk production ( $\mathrm{L}, \mathrm{g}$ or pup or day, or $\mathrm{kg} \mathrm{h}^{-1}$ day $^{-1}$ ) was estimated in three of the included studies. Three studies measured the milk yield, and these studies showed significantly increased milk yield compared with the control group. Of the three studies that used $N$. sativa seeds, only the study of Hosseinzadeh et al. (2013) used the aqueous and ethanol extracts of seeds, whereas the other three studies used the seeds themselves as part of the daily feed.

The use of small animals, such as mice, allowed administration of the extracts via oral gavage (Hosseinzadeh et al. 2013). However, in large animals, such as cow and buffaloes, $N$. sativa was offered as feed supplements (Abo El-Nor et al. 2007; Nurdin et al. 2011). One study observed increased milk production from day 8 up to day 15 (Hosseinzadeh et al. 2013), whereas study (Abo El-Nor et al. 2007) observed increased milk increases from the second week to the sixth week of treatment. Nurdin et al. (2011) did not state the period of milk collection.

Hosseinzadeh et al. (2013) showed a significant increase in milk production in the groups receiving the aqueous extract at a dose of $0.5 \mathrm{~g} \mathrm{~kg}^{-1}$ and ethanolic extract at a dose of $1 \mathrm{~g} \mathrm{~kg}^{-1}$ compared with the control. The milk production data were collected $23 \mathrm{~h}$ after gavage treatment.

A significant increase in milk yield was observed after $N$. sativa administration $(\mathrm{p}<0.01)$. It increased milk yield by 2.83 to $4.86 \%$ (799.5 L) compared with the control (777.52 L) (Nurdin et al. 2011). In buffaloes, milk yield significantly increased in the $N$. sativatreated group compared with the control group and groups treated with other herbs, such as fenugreek seeds, caraway seeds and Lepidium sativum seeds (Abo El-Nor et al. 2007).

Two studies estimated milk production using litter weight after feeding as a proxy (Al-Snafi et al. 2014; Hosseinzadeh et al. 2013). Both studies used mice, and the weight of pups was measured daily for 15 days, considering that litters are dependent on mothers' milk within 15 days and cannot nibble any food given. The result from one of the study indicates a significant increase in the weight gain of pups breastfed by mothers receiving aqueous $\left(0.5 \mathrm{~g} \mathrm{~kg}^{-1}, \mathrm{p}<0.01\right)$ and ethanolic extracts $\left(1 \mathrm{~g} \mathrm{~kg}^{-1}, \mathrm{p}<0.05\right)$ compared with the control group (Hosseinzadeh et al. 2013). Moreover, Al-Snafi et al. (2014) found that the litter weight of their lactating mice fed with $N$. sativa increased compared with the control group.

Out of the four studies, two evaluated milk composition (\%) in animals fed with $N$. sativa and used 
big animals, namely, cows, and buffaloes. Nurdin et al. (2011) determined milk lactose, fat, and protein. Abo ElNor et al. (2007) measured similar parameters with the addition of total solid (TS), solid non-fat (SNF), lactose, ash, and acidity. Milk samples were collected twice daily, and all data were recorded daily for each animal for 12 weeks (Abo El-Nor et al. 2007). The milk sampling procedure used by Nurdin et al. (2011) was not clearly stated. Milk fat did not differ significantly in both groups; however, a significant decrease in milk protein $(2.56 \%)$ was observed in the $N$. sativa group compared with the control $(3.56 \%)$ in the study conducted by Nurdin et al. (2011). TS, SNF, ash, acidity, and lactose showed no significant differences observed between the treated group and control. Only milk lactose was significantly higher in the treated group than control groups in a study conducted by Abo El-Nor et al. (2007).

Two studies investigated the safety of $N$. sativa consumption in the animals (Al-Snafi et al. 2014; Hosseinzadeh et al. 2013). One study performed an acute toxicity study to determine the safety of $N$. sativa (Hosseinzadeh et al. 2013), whereas another study used blood and specimens obtained from the liver, kidney, intestine, and stomach, which were further processed for histological examinations (Al-Snafi et al. 2014). In acute toxicity test, different doses $(0.5,2,8,16$, and $32 \mathrm{~g} \mathrm{~kg}^{-1}$ ) of the aqueous and ethanolic extracts of $N$. sativa were administered orally and intraperitoneally to a group of six mice. After 24 and $48 \mathrm{~h}$ of treatment, the number of mortality was recorded. The result from the study indicated no mortality in both aqueous and ethanolic extracts administered orally. However, the intraperitoneal route of administration of aqueous and ethanolic extracts recorded $\mathrm{LD}_{50}$ values of 4.23 and 4.9 $\mathrm{g} \mathrm{kg}^{-1}$, respectively, which were considered slightly toxic according to toxicity classification. In the histological, biochemical and hematological study by Al-Snafi et al. (2014), the side effects were not apparent.

In summary, the galactagogue action of $N$. sativa highlighted in the selected studies may be attributed to two main factors. First, $N$. sativa stimulates prolactin, a key hormone in breastfeeding that promotes breast milk production and breast tissue growth. $N$. sativa seeds contain estrogenic constituents, such as t-anethole (1 to $4 \%$ ) (Huchchannanavar et al. 2019). It may promote menstruation, facilitate birth, and increase milk secretion. Anethole has a similar structure to dopamine and may act as a competitive antagonist at the dopamine receptor site. Given that dopamine is a prolactin inhibitor, the binding of anethole at dopamine receptor sites may eliminate the inhibitory effect of dopamine on prolactin. Consequently, additional prolactin is released. Second, the constituents in the $N$. sativa seed help improve rumen ecology (Nurdin et al. 2011). N. sativa seeds contain $28 \%$ to $36 \%$ of fixed oil, saponin, alkaloid, and proteins and
$0.4 \%$ to $2.5 \%$ of essential oil (Hajhashemi et al. 2004). Saponin helps achieve a balance of microbes in the rumen by depressing the numbers of pathogenic microbes. The numbers of rumen bacteria and the total amount of volatile fatty acid (VFA) increase following the reduction of $\mathrm{NH}_{3}$ concentration. Numerous rumen bacteria are responsible for increasing VFA production, thereby increasing the production of milk or meat in dairy cows. $N$. sativa oil consists of approximately 35 to $38 \%$ fats, $35 \%$ carbohydrates and $21 \%$ proteins (AI-Jassir 1992.). These contents represent a high energy source that may play a role in the galactagogue effect of $N$. sativa (AlSnafi et al. 2014).

\section{CONCLUSION}

This review concluded that $N$. sativa has galactagogue effects in animals as demonstrated by serum prolactin level, breast tissue changes, milk composition, and milk production. Thus, $N$. sativa can be developed as an herbal supplement that can be consumed by breastfeeding mothers. However, further research should be conducted to study the effect of this herb on humans.

\section{ACKNOWLEDGEMENTS}

This study was supported by Geran Amrus Medic Sdn. Bhd and Universiti Kebangsaan Malaysia Medical Centre Fundamental Grant (FF-2017-020).

\section{REFERENCES}

Abdulelah, H.A.A. \& Zainal-Abidin, B.A.H. 2007. In vivo anti-malarial tests of Nigella sativa (Black Seed) different extracts. American Journal of Pharmacology and Toxicology 2(2): 46-50.

Abo El-Nor, S.A.H., Khatab, H.M., Al-Alamy, H.A., Salem, F.A. \& Abdou, M.M. 2007. Effect of some medicinal plants seeds in the rations on the productive performance of lactating buffaloes. International Journal of Dairy Science 2(4): 348-355.

Alemi, M., Sabouni, F., Sanjarian, F., Haghbeen, K. \& Ansari, S. 2013. Anti-inflammatory effect of seeds and callus of Nigella sativa L. extracts on mix glial cells with regard to their thymoquinone content. Journal of the American Association of Pharmaceutical Scientists 14(1): 160-167.

Ali, B.H. \& Blunden, G. 2003. Pharmacological and toxicological properties of Nigella sativa. Phytotherapy Research 17: 299-305.

Aljabre, S.H.M., Alakloby, O.M. \& Randhawa, M.A. 2015. Review. Dermatological effect of Nigella sativa. Journal of Dermatologic Surgery 19: 92-98.

Al-Jassir, M.S. 1992. Chemical composition and microflora of black cumin (Nigella sativa L.) seeds growing in Saudi Arabia. Food Chemistry Journal 45: 239-242.

Al-Snafi, A.E., Majid, J.W. \& Talab, T.A. 2014. Galactagogue action of Nigella sativa seeds. IOSR Journal of Pharmacy 4(6): 58-61.

Anderson, P.O. 2013. The galactogogue banwagon. Journal of Human Lactation 29(1): 7-10. 
Anstey, E.H., Shoemaker, M.L., Barrera, C.M., O’Neil, M.E., Verma, A.B. \& Holman, D.M. 2017. Breastfeeding and breast cancer risk reduction: Implications for black mothers. American Journal of Preventive Medicine 53(3S1): S40-S46.

Azadi, H.G. \& Farzaneh, N. 2010. Comparison of two regimens of Nigella sativa extract for treatment of subclinical mastitis caused by Staphylococcus aureus. American Journal of Applied Sciences 7(9): 1210-1214.

Babazadeh, B., Sadeghnia, H.R., Kapurchal, E.S., Parsaee, H., Nasri, S. \& Tayarani-Najaran, Z. 2012. Protective effect of Nigella sativa and thymoquinone on serum/glucose deprivation-induced DNA damage in PC12 cells. Avicenna Journal of Phytomedicine 2(3): 125-132.

Boskabady, M.H. \& Shirmohammadi, B. 2002. Effect of Nigella sativa on isolated guinea pig trachea. Archives of Iranian Medicine 5: 103-107.

Doggrell, S.A. \& Hancox, J.C. 2014. Cardiac safety concerns for domperidone, an antiemetic and prokinetic, and galactogogue medicine. Expert Opinion Drug Safety 13(1): 131- 138.

El Rabey, H.A., Al-Seeni, M.N. \& Bakhashwain, A.S. 2017. The antidiabetic activity of Nigella sativa and propolis on streptozotocin-induced diabetes and diabetic nephropathy in male rats. Evidence-Based Complementary Alternative Medicine 2017: 1-14.

El Shenawy, N.S., Soliman, M.F. \& Reyad, S.I. 2008. The effect of antioxidant properties of aqueous garlic extract and Nigella sativa as anti-schistosomiasis agents in mice. Revista do Instituto de Medicina Tropical de Sao Paulo 50(1): 29-36.

Erboga, M., Kanter, M., Aktas, C., Sener, U., Fidanol Erboga, Z., Bozdemir Donmez, Y. \& Gurel, A. 2016. Thymoquinone ameliorates cadmium-induced nephrotoxicity, apoptosis, and oxidative stress in rats is based on its anti-apoptotic and anti-oxidant properties. Biological Trace Elements Research 170(1): 165-172.

Hajhashemi, V., Ghannadi, A. \& Jafarabadi, H. 2004. Black cumin seed essential oil as a potential analgesic and antiinflammatory. Phytotheraphy Research 18(3): 195-199.

Hale, T.W. \& Hartmann, P.E. 2007. Hale and Hartmann's Textbook of Human Lactation. Plano, TX: Springer.

Hale, T.W., Kendall-Tackett, K. \& Cong, Z. 2018. Domperidone versus metoclopramide: Self-reported side effects in a large sample of breastfeeding mothers who used these medications to increase milk production. Clinical Lactation 9(1): 10-17.

Haron, H., Grace-Lynn, C. \& Shahar, S. 2014. Comparison of physicochemical analysis and antioxidant activities of Nigella sativa seeds and oils from Yemen, Iran and Malaysia. Sains Malaysiana 43(4): 535-542.

Hosseinzadeh, H., Tafaghodi, M., Mosavi, M.J. \& Taghiabadi, E. 2013. Effect of aqueous and ethanolic extracts of Nigella sativa seeds on milk production in rats. Journal of Acupunture and Meridien Studies 6(1): 18-23.

Huchchannanavar, S., Yogesh, L.N. \& Prashant, S.M. 2019. The black seed Nigella sativa: A wonder seed. International Journal of Chemical Studies 7(3): 1320-1324.

Institute for Public Health (IPH). The National Health and Morbidity Survey (NHMS) 2016: Maternal and Child Health Volume II. Kuala Lumpur: Institute for Public Health, National Institutes of Health, Ministry of Health Malaysia.

Jaarin, K., Foong, W.D., Yeoh, M.H., Kamarul, Z.Y.N., Qodriyah, H.M.S., Azman, A., Zuhair, J.S.F., Juliana, A.H. \& Kamisah,
Y. 2015. Mechanisms of the antihypertensive effects of Nigella sativa oil in L-NAME-induced hypertensive rats. Clinics 70(11): 751-757.

Jordan, S.J., Cushing-Haugen, K.L., Wicklund, K.G., Doherty, J.A. \& Rossing, M.A. 2012. Breast-feeding and risk of epithelial ovarian cancer. Cancer Causes Control 23(6): 919-927.

Kul'ko, A.B., Kisl, O.V., Sadykova, V.S., Mikhailov, V.F., Vasilieva, I.M., Shulenina, L.V., Zasukhina, G.D. \& Rogozhin, E.A. 2016. Investigation of thionins from black cumin (Nigella sativa L.) seeds showing cytotoxic, regulatory and antifungal activity. Antibiotiki i Khimioterapiya 61(910): 8-16.

Liu, H., Hua, Y., Luo, H., Shen, Z., Tao, Z. \& Zhu, X. 2015. An herbal galactagogue mixture increases milk production and aquaporin protein expression in the mammary glands of lactating rats. Evidence-Based Complementary and Alternative Medicine 2015: 1-6.

Nasuti, C., Bordoni, L., Fedeli, D. \& Gabbianelli, R. 2019. Effect of Nigella sativa oil in a rat model of adjuvant-induced arthritis. Multidisciplinary Digital Publishing Institute Proceedings 342(8): 1-17.

Ng, W.K., Yazan, L.S. \& Ismail, M. 2011. Thymoquinone from Nigella sativa was more potent than cisplatin in eliminating of $\mathrm{SiHa}$ cells via apoptosis with down-regulation of Bcl-2 protein. Toxicology In Vitro 25(7): 1392-1398.

Nickavar, B., Mojab, F., Javidnia, K. \& Amoli, M.A. 2003. Chemical composition of the fixed and volatile oils of Nigella sativa L. from Iran. Zeitschrift fur Naturforschung C. Juornal 58(9-10): 629-631.

Nurdin, E., Amelia, T. \& Makin, M. 2011. The effects of herbs on milk yield and milk quality of mastitis dairy cow. Journal of the Indonesian Tropical Animal Agriculture 36(2): 104-108.

Othman, N., Lamin, R.A.C. \& Othman, C.N. 2014. Exploring behavior on the herbal galactagogue usage among Malay lactating mothers in Malaysia. Procedia-Social and Behavioral Sciences 153: 199-208.

Sharma, K. \& Bhatnagar, M. 2011. Asparagus racemosus (Shatavari): A versatile female tonic. International Journal of Pharmaceutical and Biological Archive 2(3): 855-863.

Shuid, A.N., Mohamed, N., Mohamed, I.N., Othman, F., Suhaimi, F., Mohd Ramli, E.S., Muhammad, N. \& Soelaiman, I.N. 2012. Nigella sativa: A potential antiosteoporotic agent. Evidence-Based Complementary and Alternative Medicine 2012: Article ID. 696230.

Tengku Alina, T.I., Wan Abdul Manan, W.M. \& Mohd Isa, B. 2013. Factors predicting early discontinuation of exclusive breastfeeding among women in Kelantan, Malaysia. Health and the Environment Journal 4(1): 42-54.

World Health Organization. 2017. Global Targets 2025: To Improve Maternal, Infant and Young Child Nutrition. http://www.who.int/nutrition/global-target-2025/ en/. Accessed on 1 June 2017.

Yesmin, F., Rahman, Z., Dewan, J.F., Helali, A.M., Rahman, N.I.A., Alattraqchi, A.G., Ahmed, A., Yousuf, R., Salam, A. $\&$ Haque, M. 2013. Hepato-protective role of the aqueous and n-hexane extracts of Nigella sativa Linn. in experimental liver damage in rats. Asian Journal of Pharmaceutical and Clinical Research 6(3): 205-209. 
Zaoui, A., Cherrah, Y., Mahassini, N., Alaoui, K., Amarouch, H. \& Hassar, M. 2002. Acute and chronic toxicity of Nigella sativa fixed oil. Phytomedicine 9(1): 69-74.

Zuppa, A.A., Sindico, P., Orchi, C., Carducci, C., Cardiello, V. \& Romagnoli, C. 2010. Safety and efficacy of galactogogues: Substances that induce, maintain and increase breast milk production. Journal of Pharmacy Pharmaceutical Sciences 13: $162-174$.
Department of Physiology, Faculty of Medicine Universiti Kebangsaan Malaysia

Jalan Yaacob Latif

56000 Cheras, Kuala Lumpur

Malaysia

*Corresponding author; email: adilahamid@gmail.com

Received: 25 September 2019

Accepted: 23 March 2020 